\title{
Support Resources \\ for Military Caregivers
}

\section{Caregivers: You are not alone}

RAND research estimates that there are 5.5 million people in the United States who provide informal care for veterans with disabling injuries or illnesses. These individuals-who we label military caregivers - are spouses, parents, siblings, friends, neighbors, and children of our nation's veterans. They are critical to veterans' reintegration and recovery, helping them to live longer and better-quality lives.

\section{Caregiving can be a heavy burden}

Many caregivers provide care while balancing work and family obligations. Our study revealed that caregiving can take a lot of time and impose a heavy burden on caregiver health and wellbeing. Finding help and support can minimize this burden and improve their well-being.

\section{Finding help}

The RAND study identified more than 120 programs that provide support services for military caregivers. Finding the right program and support can be challenging. There are many places to begin your search, but you will need to assess whether specific programs match your needs. In our review of programs for military caregivers, we found that these support services fall into a few basic categories (see box).

\section{Accessing federal and state benefits and programs}

You may be eligible for benefits and services through the federal government, some of which are administered by state or local county government through designated agencies.

\section{Categories of support services for military caregivers}

- Respite care: Care provided by someone other than the caregiver to give the caregiver a temporary break

- Patient advocate or case manager: An individual who acts as a liaison between the service member or veteran and health care and service care providers

- Helping hand: Direct support such as loans, donations, housing support, or transportation assistance

- Financial stipend: Compensation for a caregiver's time devoted to caregiving activities or for lost wages

- Structured social support: Online or in-person support groups for caregivers or military family members

- Religious support: Religious- or spiritualbased counseling

- Structured wellness activities: Organized activities, such as fitness classes or stress relief lessons, that focus on improving well-being.

- Training can be an effective way to both enhance the care and well-being of the wounded, ill, or injured, and also reduce caregiver burden.

- Some programs also offer health care and mental health care services specifically for caregivers outside of traditional channels. 
Department of Veterans Affairs (VA) offers a series of programs and benefits for caregivers. Respite care, social support services, aid and attendance benefits and training are also available. More information can be found at www.caregiver.va.gov. Caregivers of veterans who served post-9/11 may also be eligible for the Program of Comprehensive Assistance for Family Caregivers. You can check your eligibility at the link listed here, or reach out to the Caregiver Support Coordinator at your local VA hospital: www.va.gov/healthbenefits/resources/Caregiver_ Eligibility_Check.asp

\section{Department of Defense (DoD) Special Compensa-} tion for Assistance with Activities of Daily Living (SCAADL) financial stipends are available for activeduty service members who served post-9/11; have permanent, catastrophic injuries; are in outpatient care; and have a designated primary caregiver. Check through your Service Branch's Wounded Warrior Program or Warrior Transition Unit.

\section{Medicaid Home- and Community-Based Services} (HCBS). Through your state, you may be eligible for a wide range of services through the Medicaid HCBS programs. For more information, visit www.caregiver.org/home-and-community-basedservices-program-hcbs

State and Local Respite Care Services. Many states have state-based respite coalitions and funding through the Lifespan Respite Care Act to support additional respite services for caregivers. For more information, visit www.archrespite.org/respitelocator

\section{Accessing health care}

Ensuring that you have access to a regular source of health care is important for your own health and well-being. Service members and families who have not qualified for VA benefits, are in the process of qualifying for them, or who are not accessing TRICARE insurance may be eligible for health care coverage through their employer, memberbased organizations such as AARP, the new health insurance exchanges, Medicaid, or Medicare. For more information, visit www.healthcare.gov/blog/4-steps-to-getting-covered-inthe-health-insurance-marketplace

\section{Protecting your own well-being}

As a military caregiver, you are contributing to the health and well-being of our nation's veterans, enabling their successful recovery and rehabilitation, and contributing to their quality of life. Whether you perform these caregiving tasks for a short period of time or for many years, caregiving can affect your own health and well-being. Getting help can minimize this impact and promote your own long-term well-being. Make sure to avail yourself of the benefits and resources available to support you and your family. These links may offer additional insights and resources on finding help:

www.militaryfamily.org/get-info/caregiver/

www.caregiver.org/

www.caregiving.org/resources

www.elizabethdolefoundation.org

www.rosalynncarter.org/resources/ www.rand.org

HEADQUARTERS CAMPUS

1776 Main Street

P.O. Box 2138

Santa Monica, California

90407-2138

TEL 310.393.0411

FAX 310.393 .4818
This brief is based on a 2014 RAND study that included a nationally representative survey of military caregivers and a comprehensive review of programs and support resources available to address the many needs of military caregivers. This study, the first of its kind, is fully documented in Ramchand R, Tanielian T, Fisher MP, Vaughan CA, Trail TE, Epley C, Voorhies P, Robbins MW, Robinson E, Ghosh-Dastidar B, Hidden Heroes: America's Military Caregivers, RR-499-TEDF, 2014 (available at www.rand.org/military-caregivers).

The RAND Corporation is a research organization that develops solutions to public policy challenges to help make communities throughout the world safer and more secure, healthier, and more prosperous. RAND is nonprofit, nonpartisan, and committed to the public interest. RAND's publications do not necessarily reflect the opinions of its research clients and sponsors.

RAND $^{\circ}$ is a registered trademark
Elizabeth Dole Foundation

CARING FOR MILITARY FAMILIES

This research was conducted by the RAND Corporation under the sponsorship of Caring for Military Families: The Elizabeth Dole Foundation. 


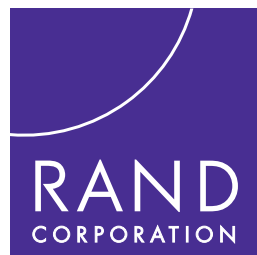

CHILDREN AND FAMILIES

EDUCATION AND THE ARTS

ENERGY AND ENVIRONMENT

HEALTH AND HEALTH CARE

INFRASTRUCTURE AND

TRANSPORTATION

INTERNATIONAL AFFAIRS

LAW AND BUSINESS

NATIONAL SECURITY

POPULATION AND AGING

PUBLIC SAFETY

SCIENCE AND TECHNOLOGY

TERRORISM AND HOMELAND SECURITY
The RAND Corporation is a nonprofit institution that helps improve policy and decisionmaking through research and analysis.

This electronic document was made available from www.rand.org as a public service of the RAND Corporation.

\section{Support RAND}

Browse Reports \& Bookstore

Make a charitable contribution

\section{For More Information}

Visit RAND at www.rand.org

Explore the RAND Corporation

View document details

\section{Research Brief}

This product is part of the RAND Corporation research brief series. RAND research briefs present policy-oriented summaries of individual published, peer-reviewed documents or of a body of published work.

\section{Limited Electronic Distribution Rights}

This document and trademark $(s)$ contained herein are protected by law as indicated in a notice appearing later in this work. This electronic representation of RAND intellectual property is provided for noncommercial use only. Unauthorized posting of RAND electronic documents to a non-RAND website is prohibited. RAND electronic documents are protected under copyright law. Permission is required from RAND to reproduce, or reuse in another form, any of our research documents for commercial use. For information on reprint and linking permissions, please see RAND Permissions. 